\title{
Immunohistochemical Markers in the Differential Diagnosis of Melanoma and Nevus in Humans
}

\author{
Marcadores Inmunohistoquímicos en el Diagnóstico \\ Diferencial de Melanoma y Nevos en Humanos
}

Nelson Quilaqueo'; Felipe Navarrete ${ }^{1}$; Cristian Sandoval2,3; Ignacio Roa ${ }^{4}$; Mario Pellón ${ }^{5}$ \& Marco Paredes ${ }^{1}$

\begin{abstract}
QUilaqUEO, N.; NAVARRETE, F.; SANDOVAL, C.; ROA, I.; PELLÓN, M. \& PAREDES, M. Immunohistochemical markers in the differential diagnosis of melanoma and nevus in humans. Int. J. Morphol., 39(5):1509-1515, 2021.

SUMMARY: Immunohistochemistry allows in situ detection of cell and extracellular components through specific antibodies. The objective was to compare the immunohistochemical expression patterns of the S-100, HMB-45 and MART-1 proteins for differential diagnosis of malignant melanoma and melanocytic nevus in human skin biopsies. Thirty-nine biopsies of human tissue were used. They were divided into two groups: 19 in malignant melanoma and 20 in melanocytic nevi. Next, the samples were fixed with paraformaldehyde and processed following the protocol for inclusion. Then, immunohistochemical staining was performed. Finally, the histological and qualitative analysis of the samples was carried out. S-100, HMB-45, and MART-1 markers showed positive immunoreaction in melanoma biopsies. HMB-45 marker was generally present with weaker expression than S-100 and MART-1 in melanocytic nevus biopsies. No expression pattern was observed which specifically associates one or more markers with some types of histopathological diagnosis. Immunohistochemistry is fundamental in differential diagnosis of melanomas and melanocytic nevi. However, there is no antibody or set of antibodies which allows unequivocal diagnosis between melanoma and nevus. It is therefore necessary to analyze with care the expression pattern and location of the lesion using standard morphological characteristics.
\end{abstract}

KEY WORDS: Antigen antibody complex; Immunohistochemistry; Immunohistochemical markers; Pathology.

\section{INTRODUCTION}

Immunohistochemistry (IHC) combines a series of techniques and protocols which allow in situ detection of cell and extracellular components (antigens) through specific antibodies, using enzymatic detection systems (Montuenga et al., 2009), based on their high specificity and affinity in recognizing and bonding to molecules. Conjugation with enzymes or fluorescent substances allows detection of minute quantities of molecules present in the tissue studied. Today, IHC is a fundamental diagnostic tool in dermal pathologies (Fuertes et al., 2013); it offers advantages over other methods (RIA, Western Blot, ELISA), and ensures that the relations between the different components analyzed are conserved, thus allowing cell identification (Martín-Lacave \& García-Caballero, 2014). IHC is used in dermal pathologies to determine the strain or differentiation of a neoplasia, and to define a prognosis; to distinguish benign from malignant neoplastic processes; to establish the molecular architecture of a tissue; and to detect infectious agents in cells or tissues (Fuertes et al.). An example of this is the study of melanoma, diagnoses of which have increased strongly in recent decades (Geller et al., 2013). One objective of these studies is to identify antibodies which will allow it to be reliably distinguished from other, non-melanocytic pathologies (Ferringer, 2015), such as melanocytic nevus. This search, however, has proved fruitless to date.

The most frequently used marker for diagnosing melanocytic lesions is the $\mathrm{S}-100$ protein, which presents high sensitivity (between $97 \%$ and $100 \%$ ), but low specificity (between $75 \%$ and $87 \%$ ) (Ohsie et al., 2008; Hoang et al., 2010). This is because it acts as a marker for

\footnotetext{
1 Departamento de Ciencias Básicas, Facultad de Medicina, Universidad de La Frontera, Temuco, Chile.

2 Departamento de Ciencias Preclínicas, Facultad de Medicina, Universidad de la Frontera, Temuco, Chile.

3 Escuela de Tecnología Médica, Facultad de Salud, Universidad Santo Tomás, Los Carreras 753, Osorno, Chile.

4 Departamento de Ciencias Básicas Biomédicas, Facultad de Ciencias de la Salud, Universidad de Talca, Chile.

5 Departamento de Especialidades Médicas, Facultad de Medicina, Universidad de La Frontera, Temuco, Chile.

Funding: DIUFRO Nº DI16-0124 Project, Universidad de La Frontera.
} 
normal melanocytes, dendritic (Langerhans) cells, histiocytes, chondrocytes, lymphocytes, skeletal and cardiac striated muscle, Schwannocytes, epithelial and myoepithelial cells of the mammary, salivary and sudoriferous glands, and cells of the glia (Morrison \& Prayson, 2000). It should be noted that neoplasias derived from these cells also express the S-100 protein, although not uniformly (Patel et al., 2002). As a result, it is necessary to use other markers, like HMB-45 and MART-1 (MelanA), generating a pool of IHC detection techniques which help to obtain more accurate diagnoses (Cho et al., 1990).

The antibody against the HMB-45 protein is a premelanosome cytoplasm marker which is relatively useful for melanocytic differentiation; however, although it is more specific than the $\mathrm{S}-100$ protein, it is much less sensitive, as studies show that the $\mathrm{S}-100$ protein is present in $78 \%$ to $93 \%$ of cases of melanoma (Gown et al., 1986; Palazzo \& Duray, 1989; Smoller et al., 1989; Sun et al., 1990; Skelton 3rd et al., 1991; Sundram et al., 2003; Ohsie et al.). It is known that the expression of the HMB-45 marker is variable, being highest in primary melanoma (77 $\%$ to $100 \%)$ and lower in metastasis $(58 \%$ to $83 \%$ ) (Ordóñez et al., 1988; Bishop et al., 1993; Zubovits et al., 2004).

The melanoma antigen recognized by $\mathrm{T}$ cells, also called MART-1 (Melan-A), is a cytoplasmic protein of melanosome differentiation. Today, it is known that this protein detects different types of melanocytic lesions in a very similar pattern to $\mathrm{S}-100$, the difference being that MART-1 less frequently detects desmoplastic melanomas (Busam et al., 1998; Prasad et al., 2001; Mangini et al., 2002; Yu et al., 2005). It is, therefore, thought that the MART-1 protein may be a specific antigen of melanocytic differentiation for melanoma cell lines (Chen et al., 1996; Jäger et al., 1996); and, therefore, more useful in diagnosis of pathologies of this type.

The objective of the present study objective was to compare the immunohistochemical expression patterns of the S-100, HMB-45 and MART-1 proteins for differential diagnosis of malignant melanoma and melanocytic nevus in human skin biopsies.

\section{MATERIAL AND METHOD}

Biological material. Biopsies of human skin with histopathological diagnosis were obtained. They were divided into two groups by their diagnosis: 19 malignant melanoma and 20 melanocytic nevi. Then, for histological and qualitative analysis, the samples were fixed with paraformaldehyde at $4 \%$ and processed following the conventional protocol for inclusion in Paraplast Plus (Paraplast® Embedding Media, McCormick Scientific, St. Louis, MO, USA). Three histological sections of $5 \mathrm{~mm}$ thickness were taken from each sample.

Immunohistochemical analysis. Paraplast Plus was eliminated with xylol and the samples were hydrated with a battery of ethanol in decreasing concentrations. The activity of the endogenous peroxidase was eliminated by incubation with perhydro ${ }^{\mathrm{TM}}\left(\mathrm{H}_{2} \mathrm{O}_{2}\right)$ at $0.3 \%$ for 10 minutes, followed by washing three times for 2 minutes each with phosphate buffer saline (PBS). Non-specific sites were blocked by incubation with blocking solution (bovine serum albumin $2 \%$ in PBS) for $20 \mathrm{~min}$. Then, the sections were incubated with the anti-S-100, anti-HMB-45 and antiMART-1 primary antibodies (Cell Marque ${ }^{\circledR}$, SigmaAldrich Co., St. Louis, MO, USA), diluted at 1:1000 under saturated moisture conditions for 5 hours at $37{ }^{\circ} \mathrm{C}$, and finally washed three times in PBS for 2 minutes. Detection was carried out with the ABC (avidin-biotin complex) indirect method, using the VECTASTAIN® Kit (Vector Laboratories ${ }^{\circledR}$, Burlingame, USA), following the manufacturers' instructions. The reaction was analyzed using diaminobenzidine solution $(0.5 \%)$ and perhydro ${ }^{\mathrm{TM}}$ $(1 \%)\left(\mathrm{DAB}-\mathrm{H}_{2} \mathrm{O}_{2}\right)$ in PBS for 5 to 10 minutes. The samples were washed with distilled water, then contrast staining was carried out with Harris hematoxylin at $3 \%$, incubated for 2 minutes. Finally, the samples were washed with tap water, dehydrated with a battery of ethanol at increasing concentrations, passed through xylol and mounted with mounting medium (Entellan, Merck \& Co., Kenilworth, NJ, USA).

Analysis and capture of digital images. The processed samples were viewed under a Leica ${ }^{\circledR}$ DM 750 microscope and photographed with a Leica ${ }^{\circledR}$ ICC50 HD camera, and processed with the Image Pro Plus 6.0 Software (Media Cybernetics Inc., Silver Spring, MD, USA).

Qualitative analysis of immunohistochemical expression. Qualitative analysis was carried out using score ranges to assess the level of immunohistochemical expression described by Fitzgibbons et al. (2014). A value range was established from "negative" (-) to "positive" (+), reported by a different number of " + " signs. The most common spectrum of categories to describe the level of immunohistochemical expression includes: "negative" (), "weak" (+), "moderate" (++), "strong" (+++) and variations of these (Raica et al., 2007; Kapoor \& Deshmukh, 2012; Bösmüller et al., 2013; Kukreja et al., 2013). 


\section{RESULTS}

The immunohistochemical expression analysis of the S-100, HMB-45, and MART-1 markers in histological preparations from biopsies with diagnosis of melanoma, in 19 cases analyzed, shows that these three markers present positive immunoreaction (Figs. 1 and 2). In qualitative terms, no cleardifference was observed in the intensity of expression of these markers according to the type of histopathological

Table I. Qualitative analysis of immunohistochemical expression patterns of proteins S-100, HMB-45 and MART-1 in skin biopsies with histopathological diagnosis of malignant melanoma.

\begin{tabular}{|c|c|c|c|c|}
\hline $\mathrm{N}^{\mathbf{0}}$ & Histopathological diagnosis & S-100 & HMB-45 & MART-1 \\
\hline 1 & Ulcerated polypoid malignant melanoma & +++ & +++ & ++ \\
\hline 2 & Histological finding concordant with stage III malignant melanoma & ++ & + & + \\
\hline 3 & Nodular malignant ulcerated melanoma & - & + & + \\
\hline 4 & $\begin{array}{l}\text { Histological finding concordant with malignant melanoma in situ with } \\
\text { chronic inflammation in dermis }\end{array}$ & + & ++ & + \\
\hline 5 & Malignant epithelioid neoplasm with melanin pigment (melanoma) & ++ & ++ & ++ melanin \\
\hline 6 & Stage II malignant melanoma & + & + & - \\
\hline 7 & Metastases of malignant melanoma & ++ & ++ & ++ \\
\hline 8 & Metastases of malignant melanoma & + & ++ & + \\
\hline 9 & Histological finding with metastases of malignant melanoma & + & ++ & + \\
\hline 10 & Histological finding concordant with malignant melanoma & ++ & + & +++ \\
\hline 11 & Malignant epithelioid neoplasm with melanin pigment (melanoma) & ++ & ++ & + \\
\hline 12 & Nodular malignant ulcerated melanoma & - & ++ & + \\
\hline 13 & Histological finding concordant with stage $\mathrm{V}$ malignant melanoma & +++ & ++ & +++ \\
\hline 14 & Histological finding concordant with metastases of malignant melanoma & +++ & ++ & +++ \\
\hline 15 & Nodular malignant melanoma & + & +++ & +++ \\
\hline 16 & Melanoma in situ & + & + & + \\
\hline 17 & Melanoma in situ & + & + & + \\
\hline 18 & $\begin{array}{l}\text { Histological finding concordant with stage } \mathrm{V} \text { polypoid malignant } \\
\text { melanoma }\end{array}$ & + & ++ & + \\
\hline 19 & $\begin{array}{l}\text { Histological finding concordant with melanoma in situ (lentigo maligna } \\
\text { type) }\end{array}$ & + & + & ++ \\
\hline
\end{tabular}

-: negative; +: weak; ++: moderate; +++: strong.
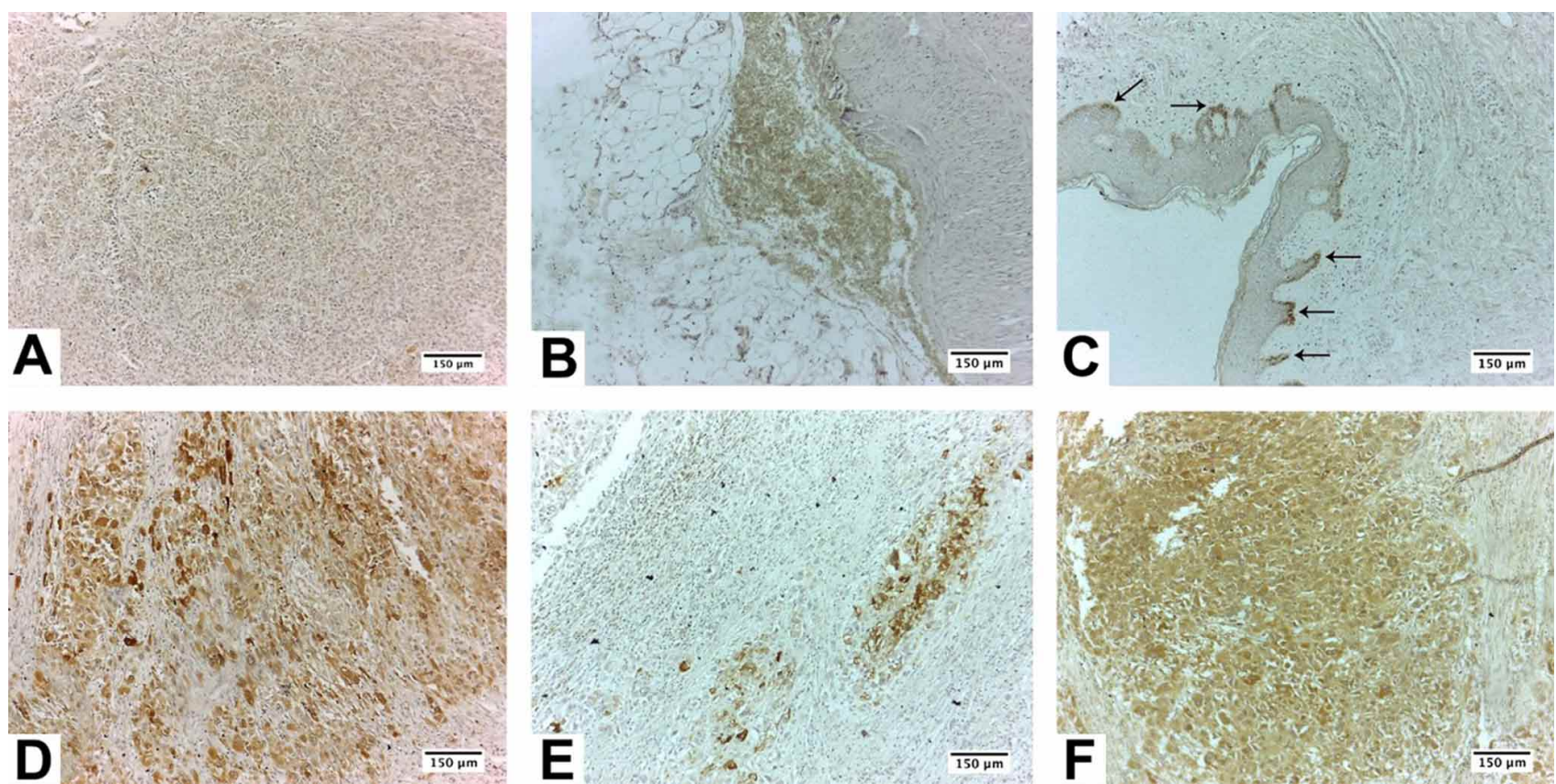

Fig. 1. Comparison of immunohistochemical expression patterns of proteins S-100, HMB-45 and MART-1 in skin biopsies with histopathological diagnosis of ulcerated nodular malignant melanoma (A, B, C) and stage V malignant melanoma (D, E, F), respectively. Small areas of immunoreaction (arrows) are observed. 
diagnosis of the biopsies assessed: a variable range of intensity of expression was found, not associated with any particular type of melanoma (Table I). The expression of S-
100 was observed to be low in some tumor outbreaks (Fig. 1A) and very intense in other cases (Fig. 1D). In the biopsies diagnosed as melanocytic nevus, in general, the expression
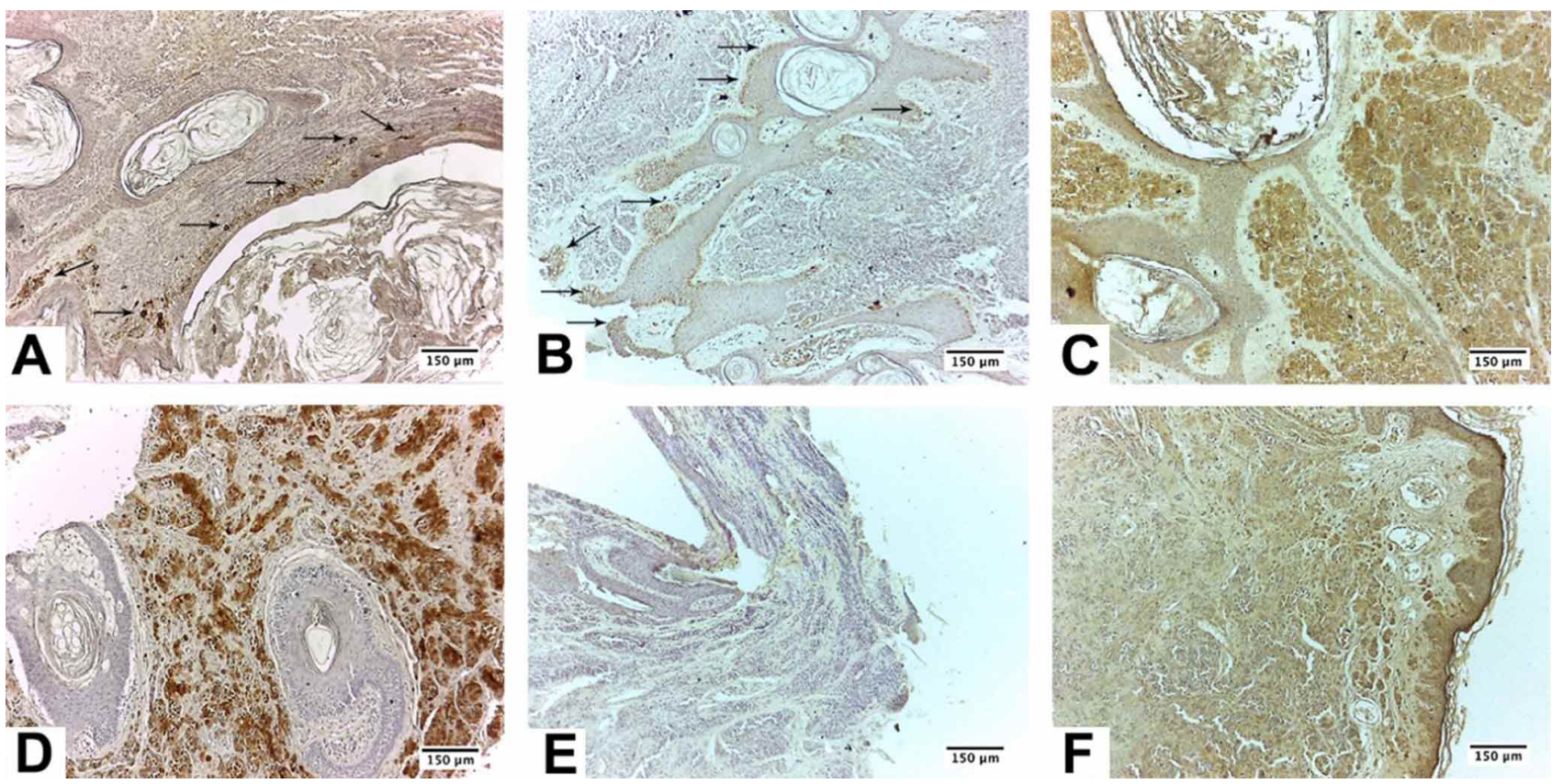

Fig. 2. Comparison of immunohistochemical expression patterns of proteins S-100, HMB-45 and MART-1 in skin biopsies with histopathological diagnosis of melanocytic dermal nevus (A, B, C) and intradermal melanocytic nevus (D, E, F), respectively. Small areas of immunoreaction (arrows) are observed.

Table II. Qualitative analysis of immunohistochemical expression of S-100, HMB-45 and MART-1 proteins in skin biopsies with histopathological diagnosis of melanocytic nevus.

\begin{tabular}{|c|c|c|c|c|}
\hline $\mathrm{N}^{\circ}$ & Histopathological diagnosis & S-100 & НMB-45 & MART-1 \\
\hline 1 & $\begin{array}{l}\text { Histological finding concordant with compound melanocytic nevus focally } \\
\text { pigmented }\end{array}$ & +++ & + & ++ \\
\hline 2 & $\begin{array}{l}\text { Concordant finding with focally pigmented intradermal melanocytic nevus } \\
\text { with as sociated focal bone metaplasia }\end{array}$ & ++ & + & ++ \\
\hline 3 & Melanocytic dermal nevus of the congenital type & +++ & + & + \\
\hline 4 & Dermal melanocytic nevus & + & + & + \\
\hline 5 & Melanocytic dermal nevus with congenital type & + & + & + \\
\hline 6 & $\begin{array}{l}\text { Histological finding concordant with intradermal melanocytic nevus } \\
\text { pigmented }\end{array}$ & - & ++ & +++ \\
\hline 7 & $\begin{array}{l}\text { Histological finding concordant with intradermal melanocytic nevus foc ally } \\
\text { pigmented }\end{array}$ & - & + & + \\
\hline 8 & Dermal melanocytic nevus & - & + & + \\
\hline 9 & Dermal melanocytic nevus & + & + & + \\
\hline 10 & Intradermal melanocy tic nevus & +++ & + & ++ \\
\hline 11 & Intradermal melanocytic nevus & + & ++ & ++ \\
\hline 12 & Intradermal melanocytic nevus & ++ & + & + \\
\hline 13 & Dermal melanocytic nevus with congenital type & +++ & + & +++ \\
\hline 14 & Atypical melanocytic nevus with halo phenomenon & - & ++ & ++ \\
\hline 15 & Pigmented intradermal melanocytic nevus with congenital type & ++ & ++ & +++ \\
\hline 16 & Intradermal melanocytic nevus & +++ & - & +++ \\
\hline 17 & Pigmented dermal mela nocy tic nevus & - & + & +++ \\
\hline 18 & Intradermal melanocytic nevus & +++ & ++ & ++ \\
\hline 19 & Pigmented intradermal melanocytic nevus & +++ & + & + \\
\hline 20 & $\begin{array}{l}\text { Pigmented intradermal melanocytic nevus with as sociated neuroid } \\
\text { involution }\end{array}$ & ++ & + & + \\
\hline
\end{tabular}

: negative; +: weak; ++: moderate; +++: strong. 
of these markers varied between the cases analyzed. This is reflected in Figure 2A, in which a dermal outbreak was observed with scarce expression of S-100; and conversely in the melanocytic nevus in Figure 2D, where intense S-100 marking was observed.

It can also be seen that HMB-45 expression was slight in a tumor outbreak described in Figure 1B, and conversely, there was intense expression in tumor tissue foci in biopsies of other origin (Fig. 1E). The MART-1 marker in tumor tissue is more intense that S-100 and HMB-45, located in some cases in the dermal-epidermal junction and in most in the dermis (Figs. 1C,F).

In biopsies with a diagnosis of melanocytic nevus, the HMB-45 marker was generally present with a weaker expression than that of S-100 and MART-1 (Figs. 2B,E; Table II). MART-1 was present in cases of melanocytic nevus with stronger expression levels than those of HMB-45. In the cases analyzed, it was observed that there was evident variation in the expression of these markers in tumor tissue with diagnosis of melanoma (Table I). In qualitative terms, no expression pattern was observed to specifically associate any of these markers with some types of histopathological diagnosis. Likewise, the samples with a diagnosis of melanocytic nevus of different types showed qualitative variation in the expression of these markers; in general, the expression of HMB-45 was lower in all the samples (Table II).

\section{DISCUSSION}

Malignant melanoma is one of the greatest mimickers in pathology, due to the variation inherent in its histological patterns (Hall et al., 2013). Correct identification, differentiating it from other benign and malignant entities, is of primordial importance; histological examination of surgical biopsies plays an important role in the diagnosis of primary cutaneous melanomas. IHC permits broad typification of tumors like carcinoma, melanoma, lymphoma or sarcoma, particularly in cases of barely differentiated malignant neoplasias in which the lineage of the cancerous cells is hard to establish by morphology alone (Biernacka et al., 2016).

According to previous results, more than $95 \%$ of primary cutaneous melanomas express S-100 (Prieto \& Shea, 2011). Our results are consistent with this, since the $S-100$ antibody against the S-100 cytoplasm protein reacted with 17 of the 19 biopsies with diagnosis of melanoma. Our findings also agree with those of Barrionuevo Cornejo et al. (1999) and Biernacka et al. who reported high sensitivity of S-100, with immunoreactivity of approximately 96 to 99
$\% ; \mathrm{S}-100$ is used as a first line melanocyte marker to evaluate poorly differentiated malignant tumors (Argenyi et al., 1994). Likewise, positive immunoreaction was found in 15 of the 20 biopsies with histopathological diagnosis of melanocytic nevus. Thus, although it allows us to identify nevi and melanomas, it does not allow differential diagnosis between them (Takahashi et al., 1984; Vanstapel et al., 1986). Although it is not specific, S100 immunomarkers almost all melanomas, usually with strong staining - in general with diffuse nuclear and cytoplasm staining (Gaynor et al., 1981).

The HMB-45 antibody is quite specific for melanocyte differentiation; expression of the HMB-45 protein was found in all of the samples diagnosed as melanoma, mainly because it detects a cytoplasm glycoprotein, GP100, present in immature melanosomes. It, therefore, indicates the formation of active melanosomes and melanocyte differentiation (Hall et al.); 19 of the 20 biopsies with a diagnosis of melanocytic nevus reacted with the same antibody. Although this antibody is much more specific than $\mathrm{S}-100$, it is also much less sensitive (Gown et al.; Palazzo \& Duray; Smoller et al.; Sun et al.; Skelton 3rd et al.), similar to Melan-A/MART-1 HMB-45 (Ordóñez, 2014); it is particularly useful for detecting the development pattern of nevi. In contrast, primary cutaneous melanomas generally express HMB-45 with an irregular pattern, presenting isolated cells or small groups throughout the dermis; the same pattern is observed in nevoid melanoma (McNutt et al., 1995). As with the intraepidermal component, HMB-45 is notable for a pagetoid growth pattern or ascendant intraepidermal migration (Hancock et al., 1991).

One of the most important melanocyte markers is the melanoma antigen recognized by T cells 1 (MART-1) (Chen et al.). This protein is detected by two different antibodies and is expressed in the majority of benign and malignant melanocytic lesions. It is thus very useful for detecting melanocytic differentiation (Jungbluth et al., 1998). However, other cells may also express this marker (Fetsch et al., 1998), and occasionally macrophages (particularly pigmented) are marked with Melan-A antibody (Trejo et al., 2002). The Melan-A antibody used in our investigation reacted with both 18 of the 19 biopsies with diagnosis of malignant melanoma and with all the samples diagnosed as melanocytic nevus, so it may be an antigen for melanocytic identification but not for cell differentiation.

\section{CONCLUSION}

We believe that immunohistochemistry plays a fundamental role in the differential diagnosis of melanomas and 
melanocytic nevi. However, there is no antibody or set of antibodies which allows unequivocal diagnosis between melanoma and nevus. It is therefore necessary to analyze with care the expression pattern and location of the lesion using standard morphological characteristics.

QUILAQUEO, N.; NAVARRETE, F.; SANDOVAL, C.; ROA, I.; PELLÓN, M. \& PAREDES, M. Marcadores inmunohistoquímicos en el diagnóstico diferencial de melanoma y nevos en humanos. Int. J. Morphol., 39(5):1509-1515, 2021.

RESUMEN: La inmunohistoquímica permite la detección in situ de componentes celulares y extracelulares a través de anticuerpos específicos. El objetivo de nuestro estudio fue comparar los patrones de expresión inmunohistoquímica de las proteínas S-100, HMB-45 y MART-1 para el diagnóstico diferencial de melanoma maligno y nevo melanocítico en biopsias de piel humana. Se utilizaron treinta y nueve biopsias de tejido humano, las que fueron divididas en dos grupos: 19 en melanoma maligno y 20 en nevos melanocíticos. A continuación, las muestras se fijaron con paraformaldehído y se procesaron siguiendo el protocolo convencional para su inclusión. Luego, se realizó la tinción inmunohistoquímica. Finalmente, se realizó el análisis histológico y cualitativo de las muestras. Los marcadores S-100, HMB45 y MART-1 mostraron inmunorreacción positiva en biopsias de melanoma. El marcador HMB-45 estuvo generalmente presente con una expresión más débil que S-100 y MART-1 en biopsias de nevo melanocítico. No se observó ningún patrón de expresión que asocie específicamente uno o más marcadores con algunos tipos de diagnóstico histopatológico. La inmunohistoquímica es fundamental en el diagnóstico diferencial de melanomas y nevos melanocíticos. Sin embargo, no existe ningún anticuerpo o panel de anticuerpos que permita un diagnóstico inequívoco entre el melanoma y el nevo. Por tanto, es necesario analizar con cuidado el patrón de expresión y la localización de la lesión utilizando características morfológicas estándar.

PALABRAS CLAVE: Complejo antígeno anticuerpo; Inmunohistoquímica; Marcadores inmunohistoquímicos; Patología.

\section{REFERENCES}

Argenyi, Z. B.; Cain, C.; Bromley, C.; Nguyen, A. V.; Abraham, A. A.; Kerschmann, R. \& LeBoit, P. E. S-100 protein-negative malignant melanoma: fact or fiction? A light-microscopic and immunohistochemical study. Am. J. Dermatopathol., 16(3):233-40, 1994.

Barrionuevo Cornejo, C.; Seminario, V.; Maita, R.; Rosas, R.; Jara, D.; Victorio, J. \& Escalante, I. Inmunohistoquímica en Lesiones Cutáneas Melanociticas: Utilidad de los Marcadores Antígeno S100, HMB45, Cromogranina A y Proteína p53. An. Fac. Med. (Perú), 60(4):257-64, 1999.

Biernacka, A.; Linos, K. D.; DeLong, P. A.; Suriawinata, A. A.; Padmanabhan, V. \& Liu, X. A case of S-100 negative melanoma: A diagnostic pitfall in the workup of a poorly differentiated metastatic tumor of unknown origin. Cytojournal, 13:21, 2016.

Bishop, P. W.; Menasce, L. P.; Yates, A. J.; Win, N. A. \& Banerjee, S. S. An immunophenotypic survey of malignant melanomas. Histopathology, 23(2):159-66, 1993.
Bösmüller, H.; Fischer, A.; Pham, D. L.; Fehm, T.; Capper, D.; von Deimling, A.; Bonzheim, I.; Staebler, A. \& Fend, F. Detection of the BRAF V600E mutation in serous ovarian tumors: a comparative analysis of immunohistochemistry with a mutation-specific monoclonal antibody and allele-specific PCR. Human Pathol., 44(3):329-35, 2013.

Busam, K. J.; Chen, Y. T.; Old, L. J.; Stockert, E.; Iversen, K.; Coplan, K. A.; Rosai, J.; Barnhill, R. L. \& Jungbluth, A. A. Expression of melan-A (MART1) in benign melanocytic nevi and primary cutaneous malignant melanoma. Am. J. Surg. Pathol., 22(8):976-82, 1998.

Chen, Y. T.; Stockert, E.; Jungbluth, A.; Tsang, S.; Coplan, K. A.; Scanlan, M. J. \& Old, L. J. Serological analysis of Melan-A(MART-1), a melanocytespecific protein homogeneously expressed in human melanomas. Proc. Natl. Acad. Sci. U. S. A., 93(12):5915-19, 1996.

Cho, K. H.; Hashimoto, K.; Taniguchi, Y.; Pietruk, T.; Zarbo, R. J. \& An, T. Immunohistochemical study of melanocytic nevus and malignant melanoma with monoclonal antibodies against S-100 subunits. Cancer, 66(4):765-71, 1990.

Ferringer, T. Immunohistochemistry in dermatopathology. Arch. Pathol. Lab. Med., 139(1):83-105, 2015.

Fetsch, P. A.; Fetsch, J. F.; Marincola, F. M.; Travis, W.; Batts, K. P. \& Abati, A. Comparison of melanoma antigen recognized by T cells (MART-1) to HMB-45: additional evidence to support a common lineage for angiomyolipoma, lymphangiomyomatosis, and clear cell sugar tumor. Mod. Pathol., 11(8):699-703, 1998.

Fitzgibbons, P. L.; Dillon, D. A.; Alsabeh, R.; Berman, M. A.; Hayes, D. F.; Hicks, D. G.; Hughes, K. S. \& Nofech-Mozes, S. Template for reporting results of biomarker testing of specimens from patients with carcinoma of the breast. Arch. Pathol. Lab. Med., 138(5):595-601, 2014.

Fuertes, L.; Santonja, C.; Kutzner, H. \& Requena, L. Inmunohistoquímica en dermatopatología: revisión de los anticuerpos utilizados con mayor frecuencia (Parte II). Actas Dermosifiliogr., 104(3):181-203, 2013.

Gaynor, R.; Herschman, H. R.; Irie, R.; Jones, P.; Morton, D. \& Cochran, A. S100 protein: A marker for human malignant melanomas? Lancet, 1(8225):869-71, 1981.

Geller, A. C.; Clapp, R. W.; Sober, A. J.; Gonsalves, L.; Mueller, L.; Christiansen, C. L.; Shaikh, W. \& Miller, D. R. Melanoma epidemic: an analysis of six decades of data from the Connecticut tumor registry. $J$. Clin. Oncol., 31(33):4172-8, 2013.

Gown, A. M.; Vogel, A. M.; Hoak, D.; Gough, F. \& McNutt, M. A. Monoclonal antibodies specific for melanocytic tumors distinguish subpopulations of melanocytes. Am. J. Pathol., 123(2):195-203, 1986.

Hall, B. J.; Schmidt, R. L.; Sharma, R. R. \& Layfield, L. J. Fine-needle aspiration cytology for the diagnosis of metastatic melanoma: systematic review and meta-analysis. Am. J. Clin. Pathol., 140(5):635-42, 2013.

Hancock, C.; Allen, B. C. \& Herrera, G. A. HMB-45 detection in adenocarcinoma. Arch. Pathol. Lab. Med., 115(9):886-90, 1991.

Hoang, M. P.; Mahalingam, M. \& Selim, M. A. Immunohistochemistry in the diagnosis of cutaneous neoplasms. Future Oncol., 6(1):93-109, 2010.

Jäger, E.; Ringhoffer, M.; Karbach, J.; Arand, M.; Oesch, F. \& Knuth, A. Inverse relationship of melanocyte differentiation antigen expression in melanoma tissues and CD8+ cytotoxic-T-cell responses: evidence for immunoselection of antigen-loss variants in vivo. Int. J. Cancer, 66(4):4706, 1996.

Jungbluth, A. A.; Busam, K. J.; Gerald, W. L.; Stockert, E.; Coplan, K. A.; Iversen, K.; MacGregor, D. P.; Old, L. J. \& Chen, Y. T. A103: An antimelan-a monoclonal antibody for the detection of malignant melanoma in paraffin-embedded tissues. Am. J. Clin. Pathol., 22(5):595-602, 1998.

Kapoor, P. \& Deshmukh, R. VEGF: A critical driver for angiogenesis and subsequent tumor growth: An IHC study. J. Oral Maxillofac. Pathol., 16(3):330-7, 2012

Kukreja, I.; Kapoor, P.; Deshmukh, R. \& Kulkarni, V. VEGF and CD 34: a correlation between tumor angiogenesis and micro vessel density-an immunohistochemical study. J. Oral Maxillofac. Pathol., 17(3):367-73, 2013.

Mangini, J.; Li, N. \& Bhawan, J. Immunohistochemical markers of melanocytic lesions: a review of their diagnostic usefulness. Am. J. Dermatopathol., 24(3):270-81, 2002. 
Martín-Lacave, I. \& García-Caballero, T. Atlas de Inmunohistoquímica. Madrid, Díaz de Santos, 2014.

McNutt, N. S.; Urmacher, C.; Hakimian, J.; Hoss, D. M. \& Lugo, J. Nevoid malignant melanoma: morphologic patterns and immunohistochemical reactivity. J. Cutan. Pathol., 22(6):502-17, 1995.

Montuenga, B. L.; Esteban, R. F. \& Calvo, G. A. Técnicas en Histología y Biología Celular. Barcelona, Elsevier Masson, 2009.

Morrison, C. D. \& Prayson, R. A. Immunohistochemistry in the diagnosis of neoplasms of the central nervous system. Semin. Diagn. Pathol., 17(3):204$15,2000$.

Ohsie, S. J.; Srantopoulos, P.; Cochran, A. J. \& Binder, S. W. Immunohistochemical characteristics of melanoma. J. Cutan. Pathol., 35(5):433-44, 2008.

Ordóñez, N. G. Value of melanocytic-associated immunohistochemical markers in the diagnosis of malignant melanoma: a review and update. Human Pathol., 45(2):191-205, 2014.

Ordóñez, N. G.; Ji, X. L. \& Hickey, R. C. Comparison of HMB-45 monoclonal antibody and S-100 protein in the immunohistochemical diagnosis of melanoma. Am. J. Clin. Pathol., 90(4):385-90, 1988.

Palazzo, J. \& Duray, P. H. Typical, dysplastic, congenital, and Spitz nevi: a comparative immunohistochemical study. Hum. Pathol., 20(4):341-6, 1989.

Patel, P.; Levin, K.; Waltz, K. \& Helm, K. F. Myxoid melanoma: immunohistochemical studies and a review of the literature. J. Am. Acad. Dermatol., 46(2):264-70, 2002.

Prasad, M. L.; Jungbluth, A. A.; Iversen, K.; Huvos, A. G. \& Busam, K. J. Expression of melanocytic differentiation markers in malignant melanomas of the oral and sinonasal mucosa. Am. J. Surg. Pathol., 25(6):782-7, 2001.

Prieto, V. G. \& Shea, C. R. Immunohistochemistry of melanocytic proliferations. Arch. Pathol. Lab. Med., 135(7):853-9, 2011.

Raica, M.; Cimpean, A. M. \& Anghel, A. Immunohistochemical expression of vascular endothelial growth factor (VEGF) does not correlate with micro vessel density in renal cell carcinoma. Neoplasma, 54(4):278-84, 2007.

Skelton 3rd, H. G.; Smith, K. J.; Barrett, T. L.; Lupton, G. P. \& Graham, J. H. HMB-45 staining in benign and malignant melanocytic lesions. A reflection of cellular activation. Am. J. Dermatopathol., 13(6):543-50, 1991.

Smoller, B. R.; McNutt, N. S. \& Hsu, A. HMB-45 recognizes stimulated melanocytes. J. Cutan. Pathol., 16(2):49-53, 1989.

Sun, J.; Morton Jr., T. H. \& Gown, A. M. Antibody HMB-45 identifies the cells of blue nevi. An immunohistochemical study on paraffin sections. Am. J. Surg. Pathol., 14(8):748-51, 1990.

Sundram, U.; Harvell, J. D.; Rouse, R. V. \& Natkunam, Y. Expression of the B-cell proliferation marker MUM1 by melanocytic lesions and comparison with S100, gp100 (HMB45), and MelanA. Mod. Pathol., 16(8):802-10, 2003.

Takahashi, K.; Isobe, T.; Ohtsuki, Y.; Akagi, T.; Sonobe, H. \& Okuyama, T. Immunohistochemical study on the distribution of alpha and beta subunits of S-100 protein in human neoplasm and normal tissues. Virchows Arch. B Cell Pathol. Incl. Mol. Pathol., 45(4):385-96, 1984.

Trejo, O.; Reed, J. A. \& Prieto, V. G. Atypical cells in human cutaneous reexcision scars for melanoma express p75NGFR, C56/N-CAM and GAP43: evidence of early Schwann cell differentiation. J. Cutan. Pathol., 29(7):397-406, 2002.

Vanstapel, M. J.; Gatter, K. C.; de Wolf-Peeters, C.; Mason, D. Y. \& Desmet, V. D. New sites of human S-100 immunoreactivity detected with monoclonal antibodies. Am. J. Clin. Pathol., 85(2):160-8, 1986.

Yu, C. H.; Chen, H. H.; Liu, C. M.; Jeng, Y. M.; Wang, J. T.; Wang, Y. P.; Liu, B. Y.; Sun, A. \& Chiang, C. P. HMB-45 may be a more sensitive maker than S-100 or Melan-A for immunohistochemical diagnosis of primary oral and nasal mucosal melanomas. J. Oral Pathol. Med., 34(9):540-5, 2005.

Zubovits, J.; Buzney, E.; Yu, L. \& Duncan, L. M. HMB-45, S-100, NK1/C3, and MART-1 in metastatic melanoma. Hum. Pathol., 35(2):217-23, 2004.

\author{
Corresponding author: \\ Dr. Marco Paredes \\ Departamento de Ciencias Básicas \\ Facultad de Medicina \\ Universidad de La Frontera \\ Avenida Francisco Salazar 01145 \\ Casilla 54-D \\ Temuco \\ CHILE
}

E-mail: marco.paredes@ufrontera.cl

Received: 17-05-2021

Accepted: 10-08-2021 